УДК 327.82:061.1

\title{
Свгеній Сафар'янс
}

аспірант

Інститут історії України НАН України 01001, Україна, Київ, вул. Михайла Грушевського, 4

E-mail: yevhenijsafarians@gmail.com

\section{РОСІЙСЬКИЙ ВПЛИВ НА ПОЗИЏЮ АВСТРЇ̈ ШОДО УГОДИ ПРО АСОЦІАЦЮ УКРАЇНИ З ЕС}

У статті розглянуто питання російського впливу на позицію Австрії щзодо Угоди про асоиіацію України з Свропейським Союзом. Доводиться, що Австрійська Республіка на початковому етапі взаємин України з СС досить схвально ставилась до украӥнських євроінтеграційних прагнень та активно підтримувала їх. Пояснено причини того, чому ставлення австрійського політикуму та громадськості до процесу украӥнської інтеграції до СС різко погіршилось після 2004 р. У статті зазначається, що саме російська пропаганда найбільше вплинула на зміну поглядів австрійських громадян та політиків щодо Украйни. Зростання євроскептицизму також тісно пов'язано з діяльністю російських інформаиійних ресурсів. Великі кошти були залучені Російською Федерацією для дискредитаџії Угоди про асоиіаџію з СС як в Україні, так $і$ в інших державах Європи.

Ключові слова: Австрія, Україна, Угода про асочіачію, Європейський Союз, російський вплив.

Yevhenij Safarians

Postgraduate Student Institute of History of Ukraine of the National Academy of Sciences of Ukraine 4, Mykhailo Hrushevskyi Street, Kyiv, 01001, Ukraine E-mail: yevhenijsafarians@gmail.com

\section{RUSSIAN INFLUENCE ON THE POSITION OF AUSTRIA IN THE CONTEXT OF THE UKRAINE - EUROPEAN UNION ASSOCIATION AGREEMENT}

The paper deals with the Russian influence on the Austrian position in the context of the Ukraine - European Union Association Agreement. The author 
proves that at start of the Ukrainian - EU relations the Republic of Austria approved Ukraine's European aspirations and actively supported them. This publication analyzes the reasons why the attitude of Austrian politicians and public society in the context of the Ukraine - EU integration sharply deteriorated after 2004. The article notes that Russian propaganda is the most influenced the change in attitudes of Austrian citizens about Ukraine. Growing euroscepticism is also closely associated with the activities of Russian information resources. Large funds were involved by the Russian Federation to discredit the Association Agreement, both in Ukraine and in other European countries. This process unfolded with new vigor during the aggression of Russia against Ukraine in the 2014-17. Some Austrian businessmen continued to collaborate with the aggressor and concluded new agreements. A significant delaying ratification of the Ukraine - European Union Association Agreement is also closely related to the impact of Russian business on Austrian politics. However, it should be noted that the Austrian side has ratified the Ukraine European Union Association Agreement. Republic of Austria acceded to the European sanctions regime against the Russian Federation and does not weaken it, despite considerable pressure from the pro-Russian part of Austrian politicians and businessmen. Austria has stood the test, and now Ukrainians have to make reciprocal steps. Ukraine should pursue a deliberate policy aimed at creating a range of partners with which to implement joint integration projects. Future cooperation between the Republic of Austria and Ukraine has an important aspect - the vision of the continuing development of integration processes in Europe.

Keywords: Austria, Ukraine, Association Agreement, European Union, Russian influence.

«Гібридна війна», яку РФ відкрито веде проти України з 20 лютого 2014 р., максимально ускладнила міжнародну ситуацію у Європі. На «роздоріжжі» опинилась і Австрія, яка після розпаду СРСР чималу увагу приділяла розвитку своїх відносин із РФ. Особливої гостроти це питання набуло після підписання, а потім набуття чинності Угодою про асоціацію між Україною та Європейським Союзом.

Актуальність обраної теми полягає в тому, що майже недослідженими виявились політичні позиції окремих держав Свропейського Союзу щодо Угоди про асоціацію України з СС. Бракує студій не тільки українських, але й іноземних авторів стосовно цієї теми, мало уваги приділено впливу російської пропаганди на політику європейських держав. Важливим $є$ той факт, що австрійська політика та настрої громадян під впливом російського бізнес-середовища та інформаційної пропаганди в період після 
2004 р. різко змінили своє ставлення щодо українського євроінтеграційного поступу.

Мета цієї статті полягає в 3'ясуванні комплексу факторів, які обумовлюють вплив РФ на позицію Австрії щодо європейської інтеграції України.

У результаті агресії РФ проти України 2014 р. гостро постало питання масштабів «гібридної війни» не лише в Україні, але й у Європі загалом. Вплив «русского мира» в культурному та інформаційному сенсі виявився потужним, а хронологічно російський інформаційний «бліцкриг» у Європі розпочався задовго до воєнної кампанії в Україні. Окремо про питання російської міграції до Австрії та збільшення російського культурно-інформаційного впливу в своїй книзі «Історія Австрії» ${ }^{1}$ пише Карл Воцелка. Володимир Кравченко в статті «Австрія. Рай у двох годинах від війни» ${ }^{2}$ досліджує рівень залежності Австрії від російського капіталу в інформаційному та політичному контексті. Про статус іміджу України в Австрії у книзі «Ігри відображень. Якою бачить Україну світ» ${ }^{3}$ згадують Тетяна Водотика та Євген Магда. Імідж України в суспільно-політичному дискурсі Австрійської Республіки аналізується в кандидатській дисертації Бориса Сулима ${ }^{4}$. Зовнішньополітичні контакти українського дипломатичного середовища з урядовими колами Австрійської Республіки розглядають у своїй праці «Зовнішня політика України в умовах глобалізації 1991-2003 рр.» ${ }^{5}$ співробітники відділу історії міжнародних відносин і зовнішньої політики України Інституту історії України НАНУ С. Віднянський, А. Мартинов та О. Горенко. Спеціальні дослідження, присвячені предмету цієї статті, в українській історіографії відсутні. Економічні аспекти відносин Австрії з Російською Федерацією у науковій статті «Австрія: відносини з Росією та наслідки для Східного партнерства $€ С »{ }^{6}$ аналізує економіст Віденського інституту міжнародних економічних досліджень Василь Астров. У цій праці декілька слів він приділяє і Україні. В іншій статті «Україна на шляху до асоціації з ЄС?» ${ }^{7}$ він подає австрійський погляд на проблеми підписання Угоди про асоціацію України з ЄС. Власну позицію щодо австрійської політики відносно Російської Федерації висвітлює Густав Грессель у розвідці «Як Європа повинна реагувати на Росію? Австрійський погляд» ${ }^{8}$. Відомий шведський політик Карл Більдт у статті «Росія, Європейський Союз та Східне партнерство» ${ }^{9}$ аналізує російську політику відносно України, зокрема стосовно Угоди про асоціацію. Австрійський історик Пітер Хавлік у своїй розвідці «Вільнюський саміт Східного партнерства: новий етап у відносинах $С С$ та Росії, не лише України» ${ }^{10}$ досліджує російський вплив на взаємовідносини СС з країнами Східного партнерства.

Першими кроками в напрямку євроінтеграційного процесу стало підписання Угоди про партнерство та співробітництво, а також прийняття 
Плану дій Україна - СС. Наступним етапом на шляху співпраці з СС стала Угода про асоціацію, й Австрійська Республіка спочатку активно підтримувала нашу державу в цьому процесі. Можливість підписання такої угоди негативно сприйняли політичні лідери Російської Федерації, які доклали максимальних зусиль для того, аби Україна припинила процес інтеграції до ЄС.

Щоби визначити, якою була позиція Австрійської Республіки щодо Угоди про асоціацію, необхідно врахувати чинники, які сприяли чи заважали підписанню цього документа.

Перспективи асоційованого та повноправного членства в СС були прописані в Постанові Верховної Ради «Про основні напрями зовнішньої політики України» від 02.07.1993 р.: «3 метою підтримання стабільних відносин 3 Європейськими Співтовариствами Україна укладе 3 ними Угоду про партнерство та співробітництво, здійснення якої стане першим етапом просування до асоційованого, а згодом — до повного iї членства у цій організації» ${ }^{11}$.

Про торговельну співпрацю та економічну інтеграцію згадувалось в Указі Президента України «Про затвердження Стратегії інтеграції України до Європейського Союзу» від 11.06.1998 p. ${ }^{12}$

19 травня 2003 р. Державною Радою з питань європейської та євроатлантичної інтеграції України була прийнята постанова №3 «Про дальші заходи у сфері європейської та євроатлантичної інтеграції України». В окремому пункті цього документа згадувалося про європейську угоду: «Розробити у тримісячний строк проект Плану дій Україна - СС щодо укладення між Україною та ЄС європейської угоди та започаткування переговорного процесу зі створення між Україною та ЄС зони вільної торгівлі, вжити заходів щодо забезпечення розгляду зазначеного проекту на саміті Україна - ЄС у жовтні 2003 р.» ${ }^{13}$.

Міністерство закордонних справ на виконання Рішення Державної Ради з питань європейської та євроатлантичної інтеграції України «Про дальші заходи у сфері європейської та євроатлантичної інтеграції України» від 19.05 .03 р. № 3 розпочало опрацьовувати проект Плану дій Україна - СС. Він передбачав «започаткування переговорного процесу зі створення між Україною та ЄС зони вільної торгівлі (ЗВТ)» ${ }^{14}$. Головним завданням цього документа визначається "реалізація заходів, які б дозволили Україні та ЄС створити передумови для переходу до якісно нового рівня відносин у форматі інтеграції та здійснити правове оформлення цих відносин шляхом укладення угоди про асоціацію» ${ }^{15}$. Міністерством закордонних справ було визначено три стратегічні напрямки співробітництва: всебічна реалізація потенціалу Угоди, просування України в напрямку досягнення відповідності Копенгагенським критеріям і подальший розвиток інтеграційного співробітництва України та $\epsilon^{16}$. 
У вересні 2003 р. в Брюсселі оприлюднено спільний угорсько-австрійський документ «Майбутнє відносин СС - Україна». У ньому зазначалося: «... передбачений СС План дій відносно України пропонує нові можливості переведення відносин на конкретну та прагматичну основу, яка цілком враховує нинішні реалії в Україні» ${ }^{17}$. Перша трьохстороння угорсько-австрійсько-українська консультація була проведена 5 лютого 2004 р. у Відні. Під час цієї зустрічі відбулись переговори із заступником Міністра закордонних справ Австрії М. Сайдіком, який запевнив українську сторону у своїй підтримці євроінтеграційних прагнень України. 14 травня 2004 р. у Відні голова австрійської делегації у Європарламенті пані У. Штейнцель у рамках заходу, що був присвячений виступу Федерального канцлера Австрії «Щодо становища нації», висловилася за надання Україні перспективи вступу до $\mathrm{CC}^{18}$. Під час зустрічі із заступником Голови прикордонної служби України О.Г. Мельниковим 13 травня 2004 р. у Відні Федеральний Міністр внутрішніх справ Австрії Е. Штрассер наголосив «на важливості посилення контактів у форматі «Ширшої Європи», насамперед, з Україною, Білоруссю та Молдовою» ${ }^{19}$.

3 цього приводу українські дипломатичні кола покладали значні надії на «сприяння Австрії у вирішенні питання лібералізації візового режиму для власників українських дипломатичних та службових паспортів» ${ }^{20}$, а також представників бізнесу, культурного та студентського обміну. Загалом представники австрійського політикуму досить позитивно висловлювались 3 приводу подальшої інтеграції України до ЄС.

Лише 2007 р. розпочались переговори про створення нової угоди, яка могла б замінити чинну Угоду про партнерство та співробітництво (1994 р.). На засіданні Ради ЄС у Брюсселі 22 липня 2008 р. міністрами закордонних справ було узгоджено назву майбутнього документа «Угода про асоціацію» ${ }^{21}$. Упродовж 2007-2012 р. тривали переговори 3 приводу узгодження основних положень Угоди про асоціацію. 19 липня 2012 р. Угода була остаточно парафована. 2013 р. iї було доопрацьовано у зв'язку зі вступом до ЄС Хорватії.

У відносинах з країнами колишнього Радянського Союзу (Україна в цьому випадку не $\epsilon$ винятком) Австрія звикла звертати увагу на реакцію Москви, оскільки саме завдяки рішенню радянського керівництва Республіка Австрія змогла здобути незалежність 1955 р. Це вияв певного роду «поваги» до Росії та іiї «зони впливу», куди входили всі пострадянські країни. Впродовж «холодної війни» австрійський уряд проводив гнучку політику й намагався лавірувати у своїй зовнішній політиці. Саме тому офіційний Відень досить уміло балансував між позиціями Москви та Вашингтона.

Після розпаду СРСР австрійське керівництво обрало новий вектор зовнішньополітичної активності: представники уряду Республіки Австрія 
з 1 січня 1993 року розпочали переговори про вступ до СС. Це політичне рішення було підтримане більшістю австрійців на референдумі 12 червня 1994 року, а вже через півроку Австрія ввійшла до складу ЄС. Відтепер австрійський уряд більше уваги приділяв зовнішньополітичній позиції свого найважливішого торговельного партнера - Німеччини.

Такий різкий поворот у австрійській зовнішній політиці примушував уряд Російської Федерації діяти активніше: до Відня 6-7 листопада 1993 р. здійснив візит Прем'єр-міністр РФ В. Черномирдін ${ }^{22} .3$ причини погіршення економічної ситуації у Східній Свропі в сер. 90-х рр. зріс потік біженців до Австрії. Особливо відчутною була мігрантська хвиля 3 Росії, яка збільшила кількість іноземців та зумовила підвищення рівня етнічної злочинності («російська мафія») ${ }^{23}$. На поч. 2000-х російський криміналітет намагається легалізувати у Австрії свій бізнес і стає неофіційним промоутером бізнес-інтересів Росії у Австрійській Республіці.

Австрійський уряд успішно здійснював свою багатовекторну політику в період з 1995 по 2004 рр.: з одного боку посилювалася співпраця бізнесу з російськими газопостачальниками, а 3 іншого продовжувалася євроінтеграційна політика. Австрія приєдналась з 1 липня 1997 року до Шенгенських угод, з 1 січня 1999 р. - до Монетарного союзу, а з 1 липня по 31 грудня 1999 р. австрійці вперше головували в структурах ЄС.

Після Помаранчевої революції 2004 р. новий український уряд висловив бажання поглиблювати відносини з $\mathrm{CC}$, зокрема і в сфері вільної торгівлі. У Росії прохолодно прийняли результат революції в Україні. У Кремлі з острахом передчували, що щось подібне може відбутися на мапі РФ, оскільки Москва була впевнена в тому, що зміна влади інспірована Заходом ${ }^{24}$.

Інтеграція Австрії до Європейського Союзу не завадила іï політиці зближення з Російською Федерацією. 32014 р. у переліку країн Russlandversteher [«тих, хто розуміє Росію». - Aвт.] опинилася і Австрійська Республіка: іiі уряд дуже скептично ставився до галузевих санкцій проти РФ через побоювання економічних наслідків. Після того, як Росія анексувала Крим і розпочала воєнні дії у Донбасі, австрійський Президент Хейнц Фішер першим з європейських лідерів у червні 2014 р. запросив Володимира Путіна до Відня ${ }^{25}$.

На політику Австрії впливала й продовжує впливати енергетична залежність від РФ: «Російський газ в енергетичному секторі Австрійської Республіки становить 70\%, нафта - 10-15\%. Залежність від російського газу дає Кремлю потужний засіб впливу на Відень, де дуже побоюються повторення наслідків російсько-українських газових воєн, у результаті яких споживачі з Центральної та Східної Європи недоодержували російський газ узимку» 26. 
Російська Федерація активно втручалася у внутрішні справи Австрії. Проросійські сили мають великий вплив на політичні рухи в країні: найбільш відомим промоутером російських інтересів є Австрійська Партія Свободи (FPÖ). Після свого стрімкого піднесення 1999 р., коли вона набрала 26,9\% голосів виборців і утворила коаліцію 3 Австрійською Народною Партією, до 2006 р. через внутрішні чвари втратила свій колишній рейтинг. 3 2007-2008 pр. нову підтримку FРӦ надала РФ, а 3 нею почала змінюватись й ідеологія партії: відтепер «православне християнство постало як головний оплот проти ісламської міграції та американського лібералізму» ${ }^{27}$. Симпатизує російському президенту В. Путіну Соціал-демократична партія Австрії(SPÖ) та частина депутатів Австрійської народної партії (ÖVP).

Австрійські політики й бізнесмени тривалий час були прихильниками проекту газогону «Південний потік», а 2014 р. — саме в розпал російської агресії - з австрійського боку підписано угоду про будівництво газопроводу. У цей час країни $\mathrm{С} \mathrm{запровадили} \mathrm{санкції} \mathrm{проти} \mathrm{Росії,} \mathrm{а} \mathrm{тому}$ «Газпром» запропонував «Турецький потік». Очільник МЗС Австрії Себастьян Курц зауважив, що Австрійська Республіка зацікавлена в тому, щоб російський газ потрапив до австрійського Баумгартена. Під час свого візиту до Росії навесні 2015 р. він заявив, що в цьому місті «єдиний газовий розподільник у Центральній Європі, тому він став би ключовим елементом у будь-якому проекті, порівнянному з “Південним потоком" ${ }^{28}$.

Австрійська нафтова компанія OMV запросила «Газпром» інвестувати у вітчизняну інфраструктуру й отримала певні надії на те, що з часом зможе стати центральноєвропейським дестриб'ютором російського газу ${ }^{29}$.

31 липня 2015 р. компанію OMV очолив Райнер Зеле. Він 5 років був головою правління німецької нафто-газової компанії Wintershall, яка долучилася до створення «Північного потоку». Самого Райнера австрійці називають «великим другом Росії».

Згадаємо про чинники, які сприяли позитивному іміджу України. На противагу активній антиукраїнській пропаганді у Австрійській Республіці, що здійснюється Росією в період з 2005 по 2017 рр., упродовж 19912004 рр. відбувалося налагодження українсько-австрійських відносин: «Кількість публікацій і телерепортажів про Україну від часу отримання незалежності в австрійських 3МІ характеризувалася тенденцією до зростання, причому пік інтересу до української проблематики закономірно припав на 2004 рік» ${ }^{30}$.

Слід нагадати й про значення української діаспори (налічує понад 12 тис. українців) у процесі формування позитивного іміджу України у Австрії. Проте діяльність здійснюється місцевими активістами, діаспорі 
бракує підтримки з боку України, зокрема: «... досі не створено науковокультурного центру України в Австрії, який би забезпечував розвиток австрійсько-українського співробітництва» ${ }^{31}$.

З 2009 року розпочався період кризи у відносинах між Україною та ЄC: це був час підготовки Угоди про асоціацію і створення зони вільної торгівлі з Європейським Союзом. У контексті подій, що відбувалися, особливу увагу варто приділити позиції Австрійської Республіки. Саме австрійські дипломатичні кола відіграли вирішальну роль у підписанні такої важливої для нас угоди.

Політичне керівництво України 2009 року почало розуміти, що швидко приєднатися до $\mathrm{CC}$ не вийде. Зовсім по-іншому постало питання євроінтеграції після приходу до влади В. Януковича. Незважаючи на політичну кризу в Україні, австрійські дипломатичні представники продовжили обіцяти підтримку нашій державі у сфері євроінтеграції. 21 серпня 2010 р. тодішній Міністр закордонних справ України К. Грищенко зустрівся у м. Зальцбург з Федеральним Міністром з європейських та міжнародних справ Республіки Австрія М. Шпіндельеггером. Останній засвідчив, що Австрія підтримує Україну в переговорах щодо безвізового режиму з СС. Міністр М. Шпіндельеггер запевнив, що Республіка Австрія на офіційному рівні підтримує підписання Угоди про асоціацію України 3 $\mathrm{CC}^{32}$. Увага була також приділена відновленню співробітництва в рамках трикутника Україна-Австрія-Угорщина.

Для закріплення відносин між державами 16-17 вересня 2010 p. Австрію з офіційним візитом відвідав Голова Верховної Ради України В. Литвин. У рамках поїздки В. Литвин провів переговори з Президентом Федеральної Ради М. Прайнедером, Президентом Національної Ради Австрії Б. Праммером та Президентом Австрії Г. Фішером. Двічі відвідував Австрію з офіційним візитом Прем'єр-міністр України М. Азаров. 4-5 жовтня 2011 р. з офіційним візитом до України прибула Президент Національної Ради Австрії Барбара Праммер.

У 2011 р. міністр закордонних справ Австрії Міхаель Шпіндельеггер узагальнив уявлення про місце України у зовнішньополітичний стратегії Альпійської Республіки наступним чином: «Україна для Австрії - вельми важливий партнер Дунайського регіону та одна 3 найбільших країн Чорноморського регіону» ${ }^{33}$.

20-21 вересня 2012 р. Міністр закордонних справ України К. Грищенко взяв участь у міжнародній конференції «Ukraine on the part to European Integration», присвяченій питанням підписання Угоди про асоціацію України з СС та подальшої інтеграції нашої держави до європейських структур. В. Янукович відвідав Австрію в доленосні для України дні 21-22 листопада $2013 \mathrm{p.}^{34}$. 
У цей час розпочався новий етап фінансової та економічної зацікавленості Австрії у співпраці з Росією, зокрема й у нафтогазовій сфері. Особливу роль стабільного посередника відводили в цій ситуації і Україні $^{35}$. Австрійське керівництво підтримувало Угоду про асоціацію між Україною та $Є С$, але в деяких політиків з'явилися сумніви щодо можливості приєднання України до Свропейського Союзу. Існує думка, що основною причиною створення «Східного партнерства» була спроба вберегти кордони $С С$ «колом друзів», які б стали буферною зоною, за умови агресії з боку Росії. У РФ також підтримували такі європейські настрої, оскільки ці буферні держави залишались у сфері політичного впливу Росії ${ }^{36}$.

30 листопада 2012 р. посол Австрії в Україні Вольф Дітріх Хайм в ефірі 5 каналу висловив власну думку щодо Угоди про асоціацію: «Австрія ніколи не кидається 3 якогось одного табору в інший. Слід пам'ятати про те, що тут є певна процедура. Йдеться про Угоду про асоціацію. Нам не потрібна тут більшість або кворум якийсь, нам потрібна згода для того, щоби ми могли реалізувати і впровадити цю угоду. Треба, щоби погодилися всі 27-м країн і Європарламент. Австрія зі свого боку виступає дуже позитивною силою в цьому питанні» ${ }^{37}$.

29 квітня 2013 р. у Відні відбулись політичні консультації заступників міністрів закордонних справ України та Австрії. Вони стосувалися виконання Порядку денного Угоди про асоціацію між Україною та ЄС. Генеральний секретар Федерального міністерства з європейських та міжнародних справ (МЗС) Республіки Австрія Йоганнес Кірле підтвердив зацікавленість та підтримку Австрії у підписанні Угоди про асоціацію між Україною та ЄС. Під час перемовин основний акцент надавався підписанню Зони вільної торгівлі (ЗВТ) під час Вільнюського саміту «Східного партнерства» 28-29 листопада 2013 p. $^{38}$

Російський уряд у цей час докладає максимальних зусиль для того, щоби призупинити процес підписання Угоди про асоціацію. РФ має досить тривалу історію використання економічних санкцій для політичного тиску на своїх сусідів: заборона на ввезення до РФ в 2006-2007 pp. грузинського вина та мінеральної води після «революції троянд» у Грузії, обмеження імпорту вина з Молдови, припинення постачання газу до України та Білорусі у зв'язку з бажанням відібрати в них газопроводи та нав'язати їм ціну на транзит, обмеження на імпорт молочної продукції 3 Литви, а також на імпорт молочної продукції та шоколаду з України, що було пов'язано з бажанням залякати український уряд перед Вільнюським самітом $^{39}$.

Обмежується ввезення українських товарів на територію РФ. Прем'єрміністр Дмитро Медведєв озвучив офіційну позицію уряду Російської 
Федерації, відповідно до якої підписання Угоди про зону вільної торгівлі України з СС призведе до припинення партнерських відносин з Росією: «Мы просто ограничим доступ этим товарам - и европейским, и украинским. В этом случае для Украины особый режим, скажем такой партнёрский режим, который действовал до сих пор, закончится» ${ }^{40}$.

На противагу позиції уряду РФ, шведський політик Карл Більдт зауважив: «Угода про зону вільної торгівлі повністю сумісна з існуючою угодою про вільну торгівлю між Україною та Росією, Свропейський Союз не несе відповідальності за ці домовленості» ${ }^{41}$.

Більшість європейських і австрійських економістів в цей час були впевнені в тому, що єдиною перепоною на шляху підписання Угоди про асоціацію України з СС може бути лише «справа Тимошенко». Попри систематичні погрози українському уряду з боку керівництва РФ, спрямовані на те, щоби запобігти зближенню України з СС, єдиним результатом таких дій, на думку віденського економіста Василя Астрова, може бути посилення впевненості українського керівництва в необхідності підписання Угоди про асоціацію 42.

Після перемоги Революції Гідності новий український уряд відновив перемовини щодо підписання Угоди: з березня розпочалися міжвідомчі переговори, а вже 27 червня 2014 р. у Брюсселі підписана Угода про асоціацію між Україною та ЄС. 16 вересня 2014 р. вона була ратифікована Верховною Радою та Європейським Парламентом ${ }^{43}$.

Австрія під впливом проросійського лобі 2015 р. опинилася в списку країн, які зволікали з ратифікацією Угоди: заплановане на 21 травня голосування перенесли на липень ${ }^{44}$.

22 травня 2015 р. у Ризі на саміті Східного партнерства під час виступу Петро Порошенко заявив, що чотири європейські держави Австрія, Італія, Греція, Кіпр - гальмують процес ратифікації Угоди про асоціацію $^{45}$.

327 червня 2015 р. процес ратифікації Угоди зрушив 3 місця. Посол Австрії при ЄС Вальтер Грахаммер повідомив: «Щодо стану справ

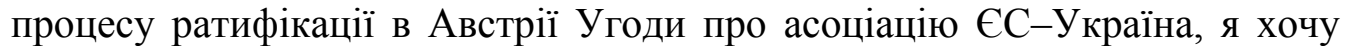
поінформувати, що це буде обговорюватися комітетом із зовнішньої політики австрійського парламенту 30 червня. I ми маємо за мету завершити ратифікаційний процес до кінця липня» ${ }^{46}$.

Як і було обіцяно В.Грахаммером, 30 червня 2015p. зовнішньополітичний комітет парламенту Австрії схвалив ратифікацію Угоди про асоціацію між Україною та ЄС. Про це повідомив посол України в Австpiї Олександр Щерба на своїй сторінці в Twitter. Також посол розповів, що за ратифікацію проголосував зовнішньополітичний комітет парламенту ${ }^{47}$. 
Австрійський дипломатичний корпус виконав свою обіцянку, і до кінця липня Австрія ратифікувала Угоду про асоціацію між Україною та ЄC попри той факт, що це голосування вважалося «проблемним» в обох палатах парламенту Австрії, оскільки правляча коаліція блокувала підготовку до ратифікації: Національна рада (нижня палата) ратифікувала Угоду 8 липня 2015p., а Федеральна рада (верхня палата) - 24 липня 2015 р. Олександр Щерба 7 серпня 2015 р. у своєму Twitter написав: «Австрійська ратифікаційна грамота відправлена в Брюссель. Австрія завершила процедуру ратифікації угоди про асоціацію. Danke!»» ${ }^{48}$. Австрія підтримала бажання українців укласти з СС Угоду про асоціацію. А вже 1 січня 2016 р. почала діяти зона вільної торгівлі України та країн Європейського Союзу ${ }^{49}$.

Остаточну ратифікацію Угоди про асоціацію України з СС було призупинено після проведення Консультативного референдуму Нідерландів щодо асоціації України та ЄС. За його результатами $61,1 \%$ виборців проголосували проти ратифікації угоди з Україною ${ }^{50}$. Щоправда, явка Референдуму склала $32,2 \%$ виборців, а це трохи вище вище рівня в $30 \%$ голосів, коли результати волевиявлення визнаються недійсними.

Кризову ситуацію з Угодою вдалося владнати в 2017 р. 15 грудня 2016 р. досягнуто компромісу у вигляді спеціальної домовленості «Рішення глав держав та урядів членів СС». 23 лютого 2017 р. повторним голосуванням Угоду про асоціацію ратифікувала Палата представників Нідерландів $^{51}, 30$ травня за Угоду проголосував Сенат ${ }^{52}$, а вже 1 червня Король Нідерландів Віллем-Олександр підписав цей документ ${ }^{53}$.

Президент України Петро Порошенко в інтерв'ю українським телеканалам повідомив, що Угода про асоціацію між Україною та Європейським Союзом вступить у дію 31 вересня 2017 p. $^{54}$

Сильні позиції проросійського лобі у Австрії вдалося зламати лише шляхом активного втручання Німеччини, яка є найважливішим австрійським торговельним партнером. Нині Австрія зберігає єдність Європейського Союзу та підтримує санкції проти Росії. Анексія Росією Криму змінює не лише регіональне, а й загальноєвропейське співвідношення сил. Це ставить австрійську політику щодо України перед класичною дилемою: віддавати пріоритет інтересам або цінностям. Цинічне слідування за інтересами 3 одночасним нехтуванням цінностей може дати тактичні переваги, але веде до неминучої стратегічної поразки. Оскільки ЄС, США, НАТО розуміють важливість зупинення путінської Росії у іiі реваншистських прагненнях, Австрія як європейська країна середніх розмірів і впливу на міжнародній арені вимушена погоджувати свій курс із загальним курсом Заходу щодо Росії.

Австрійська дипломатія загалом витримала тиск бізнесових кіл цієї країни, які вимагали перегляду режиму санкцій проти РФ, запроваджених 
у відповідь на анексію Криму й агресію на Донбасі. Це означає, що Австрія залишається важливим стратегічним партнером України серед країн-членів Свросоюзу в контексті європейської інтеграції та реалізації положень Угоди про асоціацію та про створення зони вільної торгівлі. Ключовим завданням для української дипломатії і громадянського суспільства в напрямку двосторонніх відносин із Австрією залишається систематичне формування кола друзів України в Австрії, спираючись на яких можна реалізовувати стратегічні проекти.

${ }^{1}$ Воиелка К. История Австрии. Культура, общество, политика. Пер. с нем. В.А. Брун-Цеховского, О.И. Величко, В.Н. Ковалева. Москва: Весь Мир, 2007. С.452.

2 Кравченко В. Австрія. Рай у двох годинах від війни. URL: http:/gazeta.dt.ua/ international/avstriya-ray-u-dvoh-godinah-vid-viyni-_.html (дата звернення: 30.05.2017).

${ }^{3}$ Водотика T., Магда Є. Ігри відображень. Якою бачить Україну світ. Харків: Віват, 2016. C. 234.

4 Сулим Б.В. Імідж України у суспільно-політичному дискурсі Австрійської Республіки: автореф. дис. ... канд. політ. наук: 23.00.04. Львів, 2011. 19 с.

5 Зовнішня політика України в умовах глобалізації 1991-2003 pp. К.: Генеза, 2004.

${ }^{6}$ Astrov $V$. Austria: relations with Russia and implications for the EU Eastern Partnership. Gabor Foti and Z. Ludvig (Eds.) EU-Russian relations and the Eastern Partnership: CentralEast European member state interests and positions, East European Studies Nr. 1, Institute for World Economics of the Hungarian Academy of Sciences. Budapest, 2009. P. 165-182.

${ }^{7}$ Astrov V. Ukraine: on the path towards EU association?, Monthly Report No. 11/2013, wiiw Monthly Report, No. 11, Vienna, November 2013. P. 24-26.

${ }^{8}$ Gressel G. How should Europe respond to Russia? The Austrian view. URL: http://www.ecfr.eu/article/commentary_how_should_europe_respond_to_russia_the_austrian view405 (дата звернення: 28.06.2017).

${ }^{9}$ Bildt $C$. Russia, the European Union, and the Eastern Partnership. URL: http://www.ecfr. eu/page/-/Riga_papers_Carl_Bildt.pdf (дата звернення: 28.06.2017).

${ }^{10}$ Havlik P. Vilnius Eastern Partnership Summit: Milestone in EU-Russia Relations - not just for Ukraine. Danube: Law and Economic Review (5), 2014. P. 23.

${ }^{11}$ Постанова Верховної Ради «Про основні напрями зовнішньої політики України». URL: http://zakon5.rada.gov.ua/laws/show/3360-12 (дата звернення: 30.05.2017).

12 Указ Президента України «Про затвердження Стратегії інтеграції України до Свропейського Союзу» від 11.06.1998 p. URL: http://zakon5.rada.gov.ua/laws/show/615/98 (дата звернення: 30.05.2017).

13 Галузевий державний архів Міністерства закордонних справ України (далі ГДА МЗС України), ф. 1, оп. 6, спр. 13140, арк. 10.

${ }^{14}$ ГДА МЗС України, ф. 1, оп. 6, спр. 13140, арк. 1.

${ }^{15}$ Там само.

${ }^{16}$ ГДА МЗС України, ф. 1, оп. 6, спр. 13140, арк. 1-2.

${ }^{17}$ ГДА МЗС України, ф. 1, оп. 6 (210), спр. 14160, арк. 48.

${ }^{18}$ ГДА МЗС України, ф. 1, оп. 6 (210), спр. 14160, арк. 48-49.

${ }^{19}$ ГДА МЗС України, ф. 1, оп. 6 (210), спр. 14160, арк. 50.

${ }^{20}$ ГДА МЗС України, ф. 1, оп. 6 (210), спр. 14160, арк. 49. 
21 Рада ЄC погодилась на угоду про асоціацію 3 Україною. URL: http://ua. korrespondent.net/ukraine/530635-rada-es-pogodilas-na-ugodu-pro-asociaciyu-z-ukrayinoyu (дата звернення: 30.05.2017).

22 Зовнішня політика України в умовах глобалізації 1991-2003 pp. С.В. Віднянський (Ред.). Київ: Генеза, 2004. С. 320-321.

${ }^{23}$ Воцелка К. История Австрии. Культура, общество, политика. Пер. с нем. В.А. Брун-Цеховского, О.И. Величко, В.Н. Ковалева. Москва: Весь Мир, 2007. С. 452.

${ }^{24}$ Bildt $C$. Russia, the European Union, and the Eastern Partnership. URL: http://www. ecfr.eu/page/-/Riga_papers_Carl_Bildt.pdf (дата звернення: 28.06.2017).

${ }^{25}$ Gressel G. How should Europe respond to Russia? The Austrian view. URL: http://www.ecfr.eu/article/commentary_how_should_europe_respond_to_russia_the_austrian_ view405 (дата звернення: 28.06.2017).

${ }^{26}$ Кравченко В. Австрія. Рай у двох годинах від війни. URL: http://gazeta.dt.ua/ international/avstriya-ray-u-dvoh-godinah-vid-viyni-_html (дата звернення: 30.05.2017).

${ }^{27}$ Gressel G. How should Europe respond to Russia? The Austrian view. URL: http://www.ecfr.eu/article/commentary_how_should_europe_respond_to_russia_the_austrian_ view405 (дата звернення: 28.06.2017).

${ }^{28}$ Кравченко В. Австрія. Рай у двох годинах від війни. URL: http:/gazeta.dt.ua/ international/avstriya-ray-u-dvoh-godinah-vid-viyni-_html (дата звернення: 30.05.2017).

${ }^{29}$ Gressel G. How should Europe respond to Russia? The Austrian view. URL: http://www.ecfr.eu/article/commentary_how_should_europe_respond_to_russia_the_austrian view405 (дата звернення: 28.06.2017).

${ }^{30}$ Водотика T., Магда С. Ігри відображень. Якою бачить Україну світ. Харків: Віват, 2016. С. 234.

31 Сулим Б.В. Імідж України у суспільно-політичному дискурсі Австрійської Республіки: автореф. дис. канд. політ. наук: 23.00.04. Львів, 2011. 19 с.

32 Австрія підтримуватиме Україну в питанні безвізового діалогу з $\mathrm{CC}$. URL: http://zaxid.net/news/showNews.do?avstriya_pidtrimuvatime_ukrayinu_v_pitanni_bezvizovog o_dialogu_z_yes\&objectId=1109625 (дата звернення: 30.05.2017).

${ }^{33}$ Світ про Україну та українців. В. Крилич (Упор.). Київ: Смолоскип, 2016. С. 132.

34 Почесне консульство України в м. Лінц (2017). Політичні відносини. URL: http://www.hk-ukr.at/index.php/uk/ukr-oest/2013-12-13-10-04-20 (дата звернення: 30.05.2017).

35 Astrov $V$. Austria: relations with Russia and implications for the EU Eastern Partnership. Gabor Foti and Z. Ludvig (Eds). EU-Russian relations and the Eastern Partnership: Central-East European member state interests and positions, East European Studies Nr. 1, Institute for World Economics of the Hungarian Academy of Sciences. Budapest, 2009. P. 165-182.

${ }^{36}$ Сафар'янс C. Україна та Австрійська Республіка: співробітництво в європейському інтеграційному процесі. Український історичний збірник. 2015. Вип. 18. С. 274.

${ }^{37}$ Британський посол: Україна вчинить мудріше, якщо віддасть перевагу ЄС перед Митним союзом. URL: http://news.bigmir.net/ukraine/644622-Britanskii-posol-Ykrainachinitime-rozymnishe-yaksho-viddast-perevagy-Mitnomy-souzy-pered-ES? (дата звернення: 30.05.2017).

38 Українсько-австрійські політичні консультації. URL: http://austria.mfa.gov.ua/ua/ press-center/news/11932-ukrajinsyko-avstrijsyki-politichni-konsulytaciji\#sthash.IuYbeEDL. dpuf (дата звернення: 30.05.2017).

${ }^{39}$ Havlik P. Vilnius Eastern Partnership Summit: Milestone in EU-Russia Relations - not just for Ukraine. Danube: Law and Economic Review (5), 2014. P. 23. 
40 Дмитрий Медведев встретился с членами Совета палаты Совета Федерации. URL: http://government.ru/news/5990/ (дата звернення: 27.06.2017).

${ }^{41}$ Bildt $C$. Russia, the European Union, and the Eastern Partnership. URL: http://www. ecfr.eu/page/-/Riga_papers_Carl_Bildt.pdf (дата звернення: 28.06.2017).

${ }^{42}$ Astrov V. Ukraine: on the path towards EU association?, Monthly Report No. 11/2013, wiiw Monthly Report, No. 11. Vienna, November 2013. P. 24-26.

${ }^{43}$ Угода про асоціацію. URL: http://eeas.europa.eu/delegations/ukraine/eu_ukraine/ association_agreement/index_uk.htm (дата звернення: 30.05.2017).

44 Кравченко В. Австрія. Рай у двох годинах від війни. URL: http://gazeta.dt.ua/ international/avstriya-ray-u-dvoh-godinah-vid-viyni-_.html (дата звернення: 30.05.2017).

${ }^{45}$ Хто в СС гальмує ратифікацію Угоди з Україною. URL: http://www.eurointegration. com.ua/articles/2015/05/22/7034034/ (дата звернення: 30.05.2017).

${ }^{46}$ Австрія може ратифікувати асоціацію Україна-СС до кінця липня - посол при EC. URL: http://www.eurointegration.com.ua/news/2015/06/27/7035335/ (дата звернення: 30.05.2017).

${ }^{47}$ Ратифікація асоціації в «проблемній» Австрії зрушила 3 місця. URL: http://www. eurointegration.com.ua/news/2015/06/30/7035418/ (дата звернення: 30.05.2017).

${ }^{48}$ Австрія завершила процес ратифікації Угоди про асоціацію між Україною та ЄС. URL: http://www.5.ua/polityka/avstriia-zavershyla-protses-ratyfikatsii-uhody-pro-asotsiatsiiumizh-ukrainoiu-ta-yes-89673.html (дата звернення: 30.05.2017).

49 Зона вільної торгівлі Україна-СС почала діяти 31 січня 2016 року. URL: http://www.eurointegration.com.ua/news/2016/01/1/7042941/ (дата звернення: 30.05.2017).

49 Референдум в Нідерландах: 61\% проти асоціації з Україною. URL: https://www. pravda.com.ua/news/2016/04/7/7104674/ (дата звернення: 27.06.2017).

${ }^{50}$ В Нідерландах ратифікували асоціацію, лишився ще один крок. URL: http://www.eurointegration.com.ua/news/2017/02/23/7062141/ (дата звернення: 27.06.2017).

51 Сенат Нідерландів ратифікував Угоду про асоціацію Україна-CC. URL: http://www.eurointegration.com.ua/news/2017/05/30/7066441/ (дата звернення: 27.06.2017).

52 Король Нідерландів підписав Угоду про асоціацію Україна-ЄC. URL: http://www. eurointegration.com.ua/news/2017/06/9/7066935/ (дата звернення: 27.06.2017).

53 Порошенко назвав дату старту Угоди про асоціацію між Україною та CC. URL: http://24tv.ua/poroshenko_nazvav_datu_startu_ugodi_pro_asotsiatsiyu_mizh_ukrayinoyu_ta_y es_n834288 (дата звернення: 27.06.2017).

\section{REFERENCES}

1. Astrov, V. Austria: relations with Russia and implications for the EU Eastern Partnership. Retrieved from http://www.fakprojekt.hu/docs/08-Astrov.pdf [in English].

2. Astrov, V. (2009). Austria: relations with Russia and implications for the EU Eastern Partnership. Gabor Foti and Z. Ludvig (Ed.) EU-Russian relations and the Eastern Partnership: Central-East European member state interests and positions, East European Studies. Institute for World Economics of the Hungarian Academy of Sciences. Budapest, 1, 165-182 [in English].

3. Astrov, V. (2013). Ukraine: on the path towards EU association? Monthly Report, 11, 24-26 [in English].

4. Avstriya mozhe ratyfikuvaty asotsiatsiyu Ukrayina-YeS do kintsya lypnya: posol pry YeS (2015, June 27). Retrieved from http://www.eurointegration.com.ua/news/2015/06/27/ 7035335/ [in Ukrainian]. 
5. Avstriya pidtrymuvatyme Ukrayinu $v$ pytanni bezvizovoho dialohu z YeS (2010, August 21). Retrieved from http://zaxid.net/news/showNews.do?avstriya_pidtrimuvatime ukrayinu_v_pitanni_bezvizovogo_dialogu_z_yes\&objectId=1109625 [in Ukrainian].

6. Avstriya zavershyla protses ratyfikatsiyi Uhody pro asotsiatsiyu mizh Ukrayinoyu ta YeS (2015, August 7). Retrieved from https://5.ua/polityka/avstriia-zavershyla-protsesratyfikatsii-uhody-pro-asotsiatsiiu-mizh-ukrainoiu-ta-yes-89673.html [in Ukrainian].

7. Bildt, C. Russia, the European Union, and the Eastern Partnership. Retrieved from http://www.ecfr.eu/page/-/Riga_papers_Carl_Bildt.pdf [in English].

8. Brytanskii posol Ukraina chinytyme rozymnishe yaksho viddast perevagy YeS pered Mytnym soyuzom (2012, November 30). Retrieved from: http://news.bigmir.net/ukraine/ 644622-Britanskii-posol-Ykraina-chinitime-rozymnishe-yaksho-viddast-perevagy-Mitnomysouzy-pered-ES? [in Ukrainian].

9. Dmytryy Medvedev vstretylsya s chlenamy Soveta palaty Soveta Federatsii. Retrieved from http://government.ru/news/5990/ [in Russian].

10. Embassy of Ukraine in the Republic of Austria. Ukrayinskoavstriyski politychni konsultatsiyi. (2016). Retrieved from http://austria.mfa.gov.ua/ua/press-center/news/11932ukrajinsyko-avstrijsyki-politichnikonsulytaciji\#sthash.IuYbeEDL.dpuf [in Ukrainian].

11. Gressel, G. How should Europe respond to Russia? The Austrian view. Retrieved from http://www.ecfr.eu/article/commentary_how_should_europe_respond_to_russia_the_ austrian_view405 [in English].

12. Havlik, P. (2014) Vilnius Eastern Partnership Summit: Milestone in EU-Russia Relations not just for Ukraine. Danube: Law and Economic Review (5), 21-51 [in English].

13. Khto $v$ YeS halmuye ratyfikatsiyu Uhody z Ukrayinoyu (2015, May 22). Retrieved from http://www.eurointegration.com.ua/articles/2015/05/22/7034034/ [in Ukrainian].

14. Korol' Niderlandiv pidpysav Uhodu pro asotsiatsiyu Ukrayina-YeS (2017, June 9). Retrieved from http:/www.eurointegration.com.ua/news/2017/06/9/7066935/ [in Ukrainian].

15. Kravchenko, V. (2015). Avstria. Raj v dvoch godunach vid vijny. June 26. Retrieved from http://gazeta.dt.ua/international/avstriya-ray-u-dvoh-godinah-vid-viyni-_html [in Ukrainian].

16. Krylych, V. (2016). Svit pro Ukrayinu ta ukrayintsiv. Kyiv: Smoloskyp [in Ukrainian].

17. Magda, Y. \& Vodotyka, T. (2016). Igry vidobradgen: Jakoju Ukrainu bachyt svit. Charkiv: Vivat [in Ukrainian].

18. Pochesne konsulstvo Ukrayiny v m. Lints. Politychni vidnosyny. (2017). Retrieved from http://www.hk-ukr.at/index.php/uk/ukr-oest/2013-12-13-10-04-20 [in Ukrainian].

19. Poroshenko nazvav datu startu Uhody pro asotsiatsiyu mizh Ukrayinoyu ta YeS (2017, June 25). Retrieved from http://24tv.ua/poroshenko_nazvav_datu_startu_ugodi_pro_ asotsiatsiyu_mizh_ukrayinoyu_ta_yes_n834288 [in Ukrainian].

20. Postanova Verkhovnoyi Rady Pro osnovni napryamy zovnishnoyi polityky

Ukrayiny (1993, July 2). Retrieved from http://zakon5.rada.gov.ua/laws/show/3360-12 [in Ukrainian].

21. Rada YeS pohodylas na uhodu pro asotsiatsiyu z Ukrayinoyu (2008, July 22). Retrieved from http://ua.korrespondent.net/ukraine/530635-rada-es-pogodilas-na-ugodu-proasociaciyu-z-ukrayinoyu [in Ukrainian].

22. Ratyfikatsiya asotsiatsiyi v problemniy Avstriyi zrushyla z mistsya (2015, June 30). Retrieved from http://www.eurointegration.com.ua/news/2015/06/30/7035418/ [in Ukrainian].

23. Referendum $v$ Niderlandakh: $61 \%$ proty asotsiatsiyi z Ukrayinoyu (2016, April 7). Retrieved from https://www.pravda.com.ua/news/2016/04/7/7104674/ [in Ukrainian]. 
24. Safarians, Y. (2015). Ukrayina ta Avstrijska Respublika spivrobitnycztvo v yevropejskomu integracijnomu procesi. Ukrayinskyj istorychnyj zbirnyk - Ukrainian Historical Digest, 18, 267-276. [in Ukrainian].

25. Senat Niderlandiv ratyfikuvav Uhodu pro asotsiatsiyu Ukrayina-YeS (2017, May 30). Retrieved from http://www.eurointegration.com.ua/news/2017/05/30/7066441/ [in Ukrainian].

26. Sulym, B. (2011). Imidg Ukrainy u suspilno politychnomu dyskursi Avstrijskoi Respubliky. Extended abstract of PhD thesis. Lviv [in Ukrainian].

27. Uhoda pro asotsiatsiyu (2016). Retrieved from http://eeas.europa.eu/archives/ delegations/ukraine/eu_ukraine/association_agreement/index_uk.htm [in Ukrainian].

28. Ukaz Prezydenta Ukrayiny Pro zatverdzhennya Stratehiyi intehratsiyi Ukrayiny do Yevropeyskoho Soyuzu (1998, June 11). Retrieved from http://zakon5.rada.gov.ua/laws/ show/615/98 [in Ukrainian].

29. V Niderlandakh ratyfikuvaly asotsiatsiyu, lyshyvsya shche odyn krok (2017, February 23). Retrieved from http://www.eurointegration.com.ua/news/2017/02/23/7062141/ [in Ukrainian].

30. Vocelka, K.(2007). Istoria Avstrii: kultura, obshestvo, politika. Moscow: Ves mir [in Russian].

31. Zona vilnoyi torhivli Ukrayina-YeS pochala diyaty z 1 sichnya 2016 roku (2016, January 1). Retrieved from http://www.eurointegration.com.ua/news/2016/01/1/7042941/ [in Ukrainian].

32. Zovnishnya polityka Ukrayiny v umovakh hlobalizatsiyi 1991-2003. S.V. Vidnyanskyj (Ed.). Kyiv: Geneza [in Ukrainian]. 